\title{
Supply Chain Contracts, Coordination, and Ego Networks. A Research Proposal
}

\author{
Torsten Doering, Ph.D. \\ Assistant Professor \\ Daemen College \\ USA \\ Max Winterburn, M.S. \\ International Business \\ Daemen College \\ USA
}

\begin{abstract}
The potential of interest alignment between independent firms through supply chain contracts (SCC)is not fully utilized. An exhausting amount of analytical research indicates advantages of SCCs, buttheir use in practice is limited (Cachon, 2003). This article aims to illuminate the purpose of supply chain specific contracts as an interorganizational coordination tool, as seen through the lens of organizational theory. The central question of this study relates to the conditions and antecedents of supply chain contract use, with an emphasis on vertical dyadic and secondary horizontal links between companies in a supply chain. A review shows that this topic can benefit from a connection to network theory. A three-stage research model utilizing network analysis based on case-based data collection is proposed.
\end{abstract}

\section{Keywords: Supply chain management, contracts, coordination, interest alignment, ego networks}

\section{Introduction and motivation}

Contracts are mostly used in the case of commodities and common transactions (Goffin, Lemke, \& Szwejczewski, 2006; Poppo \& Zenger, 2002). The main purpose of these contracts is to reduce risks, costs and to document the details of the transaction in a court-enforceable format. In contrast, this study understands SCCs as incentive aligning supply chain contracts that are designed to increase total supply chain performance and to motivate partners to work as if in the same organization.

A constant challenge in supply chain management is to overcome the potential shortcomings of myopic behavior, decentral decision-making and to coordinate activities between independent firms. Reduction of bullwhip effect and double marginalization can help to reduce costs, increase customer service level and overall profits (Forrester, 1958; Spengler, 1950). Paradoxically, the costs incurred due to demand fluctuations are typically higher upstream, while the ability to mitigate adverse effects may require a downstream investment. According to Flynn et al. (2010), coordination and the resulting integration are intended to improve the "flows of products and services, information, money, and decisions, to provide maximum value to the customer at low cost and high speed. Lawrence et al. (1967) define coordination as the alignment of actions between parties. Aligning incentives and designing coordination and control frameworks between companies is becoming increasingly crucial in the quest for market share and growth. The case of Cisco's 2.5 billion dollar inventory write-off, the largest in U.S. business history, is a troubling example of poorly coordinated supply chains(Narayanan \& Raman, 2004).

It has been shown that SCCs that align behavior across multiple independent firms can increase supply chain profits, but is less clear how to achieve this global optimum. This problem could be theoretically solved through the utilization of an unbiased and central decision maker outside of individual companies. In practice, companies would not surrender decision making power to an outside authority (Simchi-Levi, et al., 2008). A distribution scheme for sharing costs, risks and profits needs to be implemented. The main contribution of this paper will be an exploration of the use of SCCs, a proposal for an empirical dyadic research model, and the inclusion of network concepts in this context. The case-based method is suggested for a richer exploration of the multiplexity of inter-firm links, and since the required data is often confidential. 


\section{Literature review}

\subsection{Related organizational theory}

Institutional theory suggests three isomorphism mechanisms to explain behavior. Knowledge about the utility of contracts and coercive action could be seen as antecedents to contract implantation(Powell, 1991). Williamson (1979) described that transactions which are uncertain, occur frequently or require specific investments are more likely to take place in hierarchies. This internalization can be explained through the Transaction Cost Theory (TCT) assumptions of bounded rationality, the inability to predict all contingencies that might be relevant for contracts, and potential opportunism of economic actors(Grover \& Malhotra, 2003). The sociologists Uzzi \& Gillespie (1999)conclude that the more trading partners a firm possesses, the greater the probability to find a partner and the greater the bargaining power in a relationship. A meta-analysis shows that a refined TCT approach can predict these relational governance modes (Geyskens, Steenkamp, \& Kumar, 2006). Social capital as a resource, due to its ability to reduce internal and external transaction costs, facilitates information flows and knowledge creation across firm boundaries (Nahapiet \& Ghoshal, 1998). The lens of contingency theory is commonly applied and useful in an empirical environment (Lawrence et al., 1967). Contingencies in this context are the number and type of suppliers, stage in the supply chain or industry sector. The basic argument of Resource Dependence Theory is that a company may depend on resources in its environment, and as these critical resources can be a base of power, specific terms therefore, may be defined through contractual agreements(Pfeffer \& Salancik, 1978).Lastly, the Relational View by Dyer and Singh (1998), an extension of the Resource-Based View, proposes that dyads and networks of firms can generate relational rents above and beyond what either firm could achieve in isolation.

\subsection{Supply chain contracts}

Fugate et al. (2006) provide a concise overview of coordinating mechanisms, divided into the three classes of price coordination, non-price coordination, and flow coordination. SCCs can act as a means to achieve coordination through activities in a continuum from arm's length transactions to vertical integration (Lambert, Emmelhainz\& Gardner, 1996).However, if not coordinated, supplier and manufacturer markups will cause lower downstream stocking levels which will reduce profits. Buy-back, revenue sharing, and quantity flexibility contracts are examples that facilitate the distribution of risk from a buyer to a supplier and motivate specific investments. Buy-back contracts typically require an effective reverse logistics system and care has to be taken that demand will not be shifted to comparable products that are not covered under the buy-back agreement. Revenue sharing agreements require trustful relationships, transparent and compatible accounting as well as IT systems. A workaround for sharing cost information can be that the buyer purchases the needed inputs from a second tier supplier (Simchi-Levi et al., 2008).A pay-back contract can shift risk to the buyer by paying a fixed amount for every unit produced and not purchased. As a side effect, this mechanism can also reduce positive bias in buyer forecasts. A similar concept is a cost-sharing contract in which the buyer shares some of the production costs in return for a discounted price.

Other relevant forms of coordination are procurement terms, vendor managed inventory (VMI), collaborative planning forecasting and replenishment (CPFR), quick response and franchising. Cachon (2003) labeled this body of research 'supply chain coordination without contracts'. These forms of coordination may be less intrusive, in that they frequently align planning activities without setting goals that would require companies to share revenue, profits or other types of sensitive information. Intuitively these types of agreements should be easier to implement and execute.

Effective supply chain contracts allocate profits, share risks and costs so that firms cannot increase their gain by deviation from Pareto-optimal agreements. Information sharing, confidentiality, and contract type can influence supply chain performance (Ha \& Tong, 2008; Li \& Zhang, 2008). The systematic implementation and use of supply chain contracts may need a champion or change agent who will promote their use throughout the organization (Lambert et al., 1996). Building relationships will take time and resources, as contract related costs arise out of negotiating, monitoring and enforcing agreements. Also, it will be harder for firms to adapt quickly to a changing environment. Other authors mentioned that contracts can be seen as a lack of trust in partners, and that they may encourage opportunistic behavior (Ghoshal \& Moran, 1996).

Leading into network theory, relational forms of organization between companies can have an inherent performance-enhancingeffect, with or without formal SCCs (Poppo \& Zenger, 2002). 
The category of relational contracts is widely studied in sociology, law, and economics. These contracts assume trust and relations between parties and are mostly informal and self-enforcing, e.g., through the firm's concern for their reputation (Höhn, 2010; Kay, 2010). These contracts are flexible and are based on the mutual establishment of interest compatibility, definition of processes and performance indicators to achieve a mutually successful outcome (Bergman, 2013). The relational contract model is consistent through its internal values and wider socioeconomic factors, as well as governing norms (Macneil, 1973).

\subsection{Network forms of organization}

As a substitute for vertical integration or contracts, a rich stream of sociology and organization literature rests their assumptions on exchanges based on trust and self-enforcing behaviors, embeddedness and frequent reciprocal exchanges. The theory on networks is based on peer-to-peer interactions and cannot be appliedwithout adaptation to the supply chain management field (Borgatti \& Li, 2009).A pivotal study regarding the applicability of network theory on supply chain management by Lazzarini et al. (2001) introduces the 'netchain' concept.This model depicts supply chains as having sequential interdependencies and being coordinated by managerial decisions which intersect with pooled interdependence planes between actors within the same echelon. This model makes a crucial distinction between directed chains, such as supply chains, and planes of peer-to-peer entities (typically the subject of analysis in network studies).

What constitutes a connection between firms? Studies often define connections between firms through past financial exchanges. Content in an organizational setting can be describedby instrumental and expressive ties (Lincoln \& Miller, 1979). Expressive ties are based on social relationships and kinship for example, whereas instrumental ties could include formal reporting relationships or cooperation between organizations. While there can be socialties between companies, this study highlights instrumental ties. Content, frequency, duration, and reciprocity are important features when describing ties. Borgatti et al. (2009, p. 894) developed a typology often used by social scientists, distinguishing between similarities, social relations, interactions and flows which will be expanded in the next section.

Egonetworks provide a framework to analyze relationships around a focal node or firm. This approach is in line with the research goal of this study and the availability of SCC data. To be able to obtain confidential contract data for an entire supply chain or industry network is very unlikely. The nodes that ego is connected to are called alters. Relationships between ego and alters and among alters can bepart of an ego network. The advantage of theego vs. a whole network approach lies in the fact that firms are more likely to participate and that responses can be kept anonymous. Limitations of this approach are; common method bias, a restricted set of available analytical methods, inaccurate perception of respondents, and the partial network view. Measures such as closeness centrality are generally not applicable. Eigenvector centrality can also not be used since the connections beyond alters are not known. Ego networks are analyzed based on density, connectivity, the attributes of alters or all thereof these elements(Everett \& Borgatti, 2005).

In contrast to common relationship oriented research in SCM, ego networks allow the analysis of ties between alters. A case can be made that the ego network is a building block of the larger surrounding network(Balkundi \& Kilduff, 2006). Density in ego networks describes how many of ego's alters are connected. A dense network around a focal company can represent a form of social capital. Even though there is no theoretical link between ego betweenness and betweenness of the actor in the whole network, a simulation study showed that the two measures are highly correlated (Everett \& Borgatti, 2005). The structure of ego networks allows for computation of ego betweenness, every pair of non-adjacent alters must have a geodesic of length two which passes through ego. High betweenness centrality is synonymous with having many structural holes or being in a broker role (Burt, 1992). Structural theories can only be applied with limitations to ego networks, but approaches such as social capital present a good fit for this type of analysis.

Structural hole and weak tie theories help to understand why actors can take advantage of a position in a network. In other words, structure matters. The diversity of available resources and information and the ability to negotiate or adopt a leadership role is related to structure. The social capital theory has received considerable attention over the years, understood as the goodwill that is engendered in the fabric of social relations, and that can be mobilized to facilitate action (Adler \& Kwon, 2002). Relationships and networks can create value over and above individual knowledge or skills and are not easily imitable. The dark side of social capital was coined social liability (Gabbay \& Leenders, 2001).The principle of embeddedness is based on the notion that economic actionis embedded in social structure. Embeddedness and social capital are interrelated but distinct. 
In the case of over-embeddedness, the structure can be more constraining than beneficial (Uzzi \& Gillespie, 1999). Baum and Oliver (1992) use the term institutional embeddedness as a measure of interconnectedness and relational density. The components of embeddedness can be classified as structural, cognitive, political and cultural (Zukin \& DiMaggio, 1990).Its manifestations are repeated exchanges between partners, relations with third parties (network embeddedness), social institutions which allow for credible agreements (Rooks, Raub, Selten, \& Tazelaar, 2000) and geographic embeddedness (Hess, 2004). Relationship duration and relationship multiplexity are constructs used at the dyadic level, as well as egonetwork size and network coupling (Uzzi \& Gillespie, 1999). Network coupling refers to the amount of business dedicated to each partner and its dispersion in a portfolio of trading partners. In a landmark case study with 23 apparel companies, it was found that trust was the primary governance structure in a network with close relations(Uzzi, 1997). Many embeddedness examples are mainly based on repetitive, close-knit relationships within one industry or community. However, Granovetter (1985) points out that: “...while social relations may indeed often be a necessary condition for trust and trustworthy behavior, they are not sufficient to guarantee these and may even provide occasion and means for malfeasance and conflict on a scale larger than in their absence. The network structure can help to gain competitive and flexibility advantages while strongly relying on social dimensions versus legal contracts (Larson, 1992).Powell(1990) quotes: "Surely this patterned exchange looks more like a marriage than a one-night stand, but there is no marriage license, no common household, no pooling of assets."

While the literature on relational contracts suggests that formal contracts may not be necessary to integrate supply chains, a significant portion of this work has been based on small entrepreneurial firms and clearly defined industry segments. Managers in larger firms experience higher complexity due to the sheer number of agents involved.A downside to the relational approach is the considerable amount of energy, time and cost that is needed to establish and maintain close relationships. In addition,there is a saturation effect or over-embeddedness of teams or companies resulting in a reduction of available novel information on business partners and new technologies(Oh, Labianca, \& Chung, 2006; Shipilov \& Li, 2008).Poppo \& Zenger (2002) found that contracts can indeed act as a complement to relational exchanges without deteriorating the business relationship, wellspecified contracts may promote more cooperative, trusting and long-term exchanges. Economic and social processes can attenuate exchange hazards in relational exchanges through trust, flexibility, solidarity, reputation and information exchange.

\section{Model Development}

Three exploratory stages in the quest to strengthen the understanding of SCC are suggested. First, This study extends the Lambert et al. (1996)partnership model as shown in Figure 1,withdetailed relational characteristics as a basis for model development. The important point is that there are multiple characteristics and varying levels of integration between market and hierarchy.

\begin{tabular}{|c|c|c|c|c|c|}
\hline & \multicolumn{3}{|c|}{ Partnerships } & \multirow[b]{2}{*}{\begin{tabular}{|c|} 
Joint \\
Ventures \\
\end{tabular}} & \multirow[b]{2}{*}{$\begin{array}{c}\text { Vertical } \\
\text { Integration }\end{array}$} \\
\hline $\begin{array}{l}\text { Arm's } \\
\text { Length }\end{array}$ & Type I & Type II & Type III & & \\
\hline short & \multicolumn{3}{|c|}{ (temporal character) } & & long \\
\hline transactional & \multicolumn{3}{|c|}{ (relationship type) } & & relational \\
\hline commodity & \multicolumn{3}{|c|}{ (product/svc type) } & & specific \\
\hline low & \multicolumn{3}{|c|}{ (relationship risk) } & & high \\
\hline low & \multicolumn{3}{|c|}{ (integration effort) } & & high \\
\hline low & \multicolumn{3}{|c|}{ (business relevance) } & & high \\
\hline
\end{tabular}

Figure 1: Governance and Relationship

Transactional or common market contracts and relational supply chain contracts used predominantly in network forms of organization need to be distinguished. This study argues that supply chain contracts, written or verbal, can enhance hybrid relationships (Figure 2). 


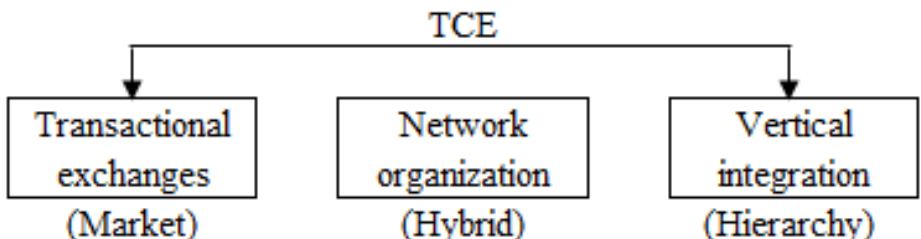

Figure 2: Principle Forms of Governance

The following propositions build on the overall assumption that supply chain contracts and relational elements are complements (Carey, Lawson, \& Krause, 2011; Poppo \& Zenger, 2002). Even the activity of negotiating and agreeing on a contract is a mutual act that requires a good understanding between partners and can further cooperative outcomes. The specification of procedures and incentive alignment frameworks will support cooperation and suppresses opportunistic behavior. Not all relevant contract elements can be anticipated but, just as most good relationships develop over time, successful cooperation may not be established overnight. As pointed out, content, frequency, duration, and reciprocity are important features when describing ties (Balkundi, Prasad, 2013). Borgatti et al. (2009) introduced a typology of ties for the social sciences with a main classification of ties that are continuous or discrete. This classification can be used for collective actors such as firms, but it is important to keep in mind that there is a distinction between individual relationships and firm ties. Different relationships between actors can exist simultaneously and may affect each other, a property knownasmultiplexity. The framework in Table 1was adapted to the supply chain context for this report (Kaneet al. 2012).

\begin{tabular}{|c|c|c|c|c|}
\hline Typology of ties & Similarities & Social Relations & Interactions & Flows \\
\hline Description & $\begin{array}{l}\text { Same location, } \\
\text { membership }\end{array}$ & $\begin{array}{l}\text { Embeddedness, } \\
\text { relational states. }\end{array}$ & Relational events & $\begin{array}{l}\text { Transfer of materials } \\
\text { and ideas }\end{array}$ \\
\hline Example & $\begin{array}{l}\text { Professional } \\
\text { Organizations }\end{array}$ & $\begin{array}{l}\text { Amicable } \\
\text { relationships, similar } \\
\text { culture }\end{array}$ & Email, contract. & $\begin{array}{l}\text { Aquiring technology, } \\
\text { sharing knowledge }\end{array}$ \\
\hline SCM context & $\begin{array}{l}\text { Active in the same } \\
\text { regional APICS } \\
\text { chapter }\end{array}$ & $\begin{array}{l}\text { Regular informal } \\
\text { meetings between } \\
\text { managers }\end{array}$ & $\begin{array}{l}\text { Mutual process } \\
\text { development. }\end{array}$ & $\begin{array}{l}\text { Sharing POS data, } \\
\text { product flow. }\end{array}$ \\
\hline
\end{tabular}

Table 1: Typology of supply chain ties

Similarities in our context can be a close geographic location or a membership in the same industry association. Social relations are also continuous and can be instrumental, task-oriented or expressive (affection, cognition).Interactions and Flows, as can be seen in Table 1, are discrete events and exchanges, such as the establishment of a contract or the exchange of tangible or intangible goods. Each different type of tie will result in a different network between the same nodes. There may be an underlying temporal sequence between these types, starting with Similarities that foster Social Relations, leading to Interactions which eventually result in product Flows. The level of analysis in this study is relationships of a focalfirm, but interactions may also consist of a bundle of personal interactions. The last category,Flows, represents the consequences of the other kind of ties. One way of analyzing networks is to analyze different networks of ties, in our context the assumption is that the establishment of a contract builds on Similarities and Social Relations and finds expression in Flows.

Proposition1: The multiplexity ofdyadic ties needs to be explored in separate ego networks for each focal firm.

Second, with the collection of a sufficient amount of cases or data on firms, constructs can be developed, and relationships between them can be explored. The following outlines previous research that builds a foundation to test a model as suggested in Figure 3.Carey et al.(2011)tested the relationship between three dimensions of social capital. Besides providing operationalization of the social capital constructs, one of the most intriguing implications is that a close social relation should not be considered as a replacement for contracts. The study also reveals that buyer performance in situations of a low social relational intensity in combination with a high a level of legal bonds seems to have an adverse effect. The aspects of social capital were initially definedin the form of three dimensions in studies with individuals and firms as levels of analysis: structural (pattern of connections), relational (trust) and cognitive (shared vision and values) (Arregle, Hitt, Sirmon, \& Very, 2007; Nahapiet \& Ghoshal, 1998; Tsai \& Ghoshal, 1998). Trust between firms is recognized to reduce uncertainty, transaction cost and is a way to learn about each other's capabilities. 
Trust has also been mentioned as an antecedent of cooperation (Gulati, 1995). Since links in an organizational environment are pluralistic, so are trusting relationships. Interorganizational trust could significantly reduce negotiation cost in reaching mutually acceptable agreements (Zaheer, McEvily, \& Perrone, 1998). Both knowledge-based trust arising from learning about other organizations over time and deterrence-based trust, from incentives to protect reputation can have positive effects (Zaheer, Gulati, \& Nohria, 2000). As a proxyfor trust, repeated interactions between firms can be included(Gulati \& Singh, 1998). Extended scales for interorganizational trust are available (Zaheer et al., 1998).

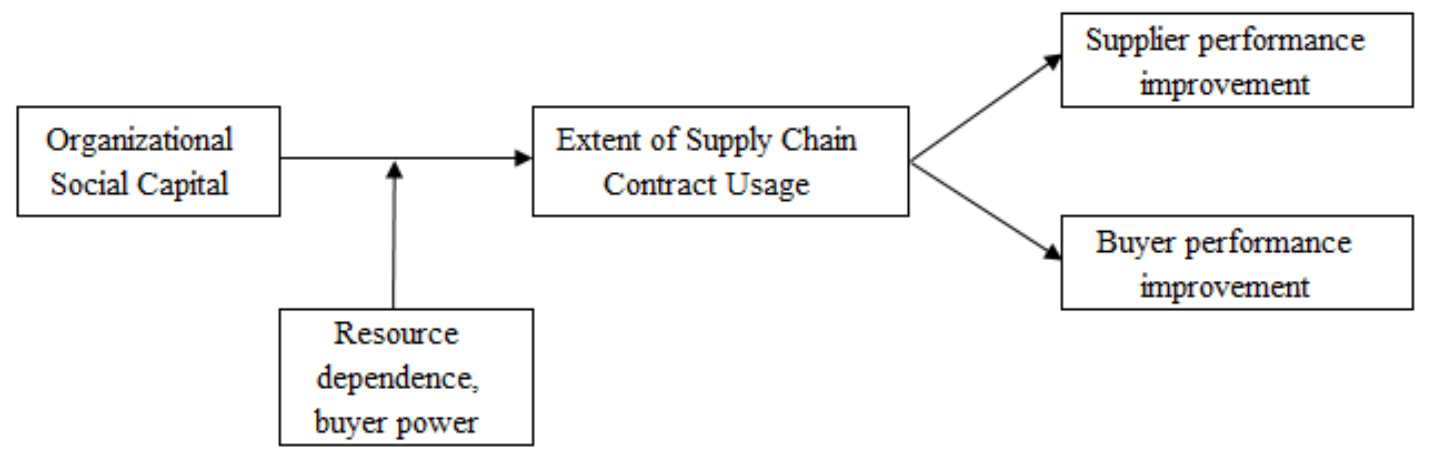

Figure 3: Proposed structural model

The structural dimension between companies can create incentives to reduce opportunistic behaviors. Antecedents of alliances and trust building processes can be found in a study of innovative small and medium-size companies (Larson, 1992). Since we argue that the establishment of contracts needs trust as a necessary condition, a closer network of ties between partners will facilitate information flow and enable firms to enter complex and difficult to monitor agreements (Shipilov \& Li, 2008). Long Lingo \& O'Mahony (2010) expressed this point through the information-benefits brokers can gain, and also discussed that it could be difficult to achieve collaboration without, or more apparent: "Execution needs collaboration." However, dense ego networks with many links between suppliers or customers could allow alters to exchange information about prices and exert pressure on ego (Hanneman \& Riddle, 2005).A broker role, on the other hand, could lead to suspicious behavior between partners, and can in addition to that counter closely linked exchanges. More and redundant ties can provide advantages when the exchange is about improving efficiency and increasing trust or reducing risk in a supply chain.

The cognitive dimension, expressed through shared representations, interpretations and systems can be measured through strategic alignment between organizations. Unlike other forms of capital, social capital is jointly owned by the parties in a relationship. Social capital ideally fosters efficiency in action, creativity and learning, and in essence all cornerstone practices in a collaborative environment. The extent of supply chain contract usage can be measured through guided questions probing the duration, extent, and impact of utilized supply chain contracts(Tsay, Nahmias, \& Agrawal, 1999). Contracts can be used to manage supply and demand in a competitive environment, in the case of high resource dependence this moderating effect may be even stronger in combination with a powerful supplier (Goffin et al., 2006; Petkova, 2013).Less essential ties may not require a closely aligned partnership and can be sufficiently satisfied with arm's length exchanges (Larson, 1992).Dimensions to monitor exchange performance are cost, time, innovativeness, quality and flexibility (Kroes \& Ghosh, 2010; Ward, et al., 1998).

Proposition2A:Organizational social capital between buyer and supplier increases the extent of supply chain contract usage.

Proposition 2B: Organizational social capital in combination with buyer power and resource dependence increases the extent of supply chain contract usage.

Proposition 2C: The extent of supply chain contract usage increases buyer and supplier performance.

Third, economic action and human behavior are influenced by interpersonal relationships and the social structure it is embedded in.This argument stresses the role in generating trust and discouraging malfeasance (Granovetter, 1985). Embeddedness at the system level can lead to preferred interactions between individuals in a community (Balkundi \& Kilduff, 2006). 
Strong ties under a social embeddedness perspective may require more intense maintenance effort and could also make the use of contracts less desirable as shown in a study analyzing relationships in the apparel industry (Uzzi, 1997).However, close cooperation, exchange of information and trust are needed to establish SCCs, especially in a dynamic business environment. Contractual incompleteness is related to the problem of information asymmetry, impactingeffective contract negotiation (Hart \& Moore, 1988).Larger corporations in contrast to often cited startup companieshave a bigger need for formal processes. Embeddedness by itself may be a necessary condition for trustworthy behavior but not sufficient to guarantee it. Aspects of embeddedness are repeated exchanges between partners and relations with third parties defined as network embeddedness (Rooks et al., 2000). Repeated information was cited as a good measure since one can typically trust inner circle information most reliably. Networks can also become an important screening device for an otherwise overwhelming amount of information, providing signals that warn and inform (Burt, 1992). Embeddedness supports the credibility of contractual undertakings. Proposition3is based on the embeddedness conceptualization by Uzzi and Gillespie (1999), measuring dimensions at the dyad and the network level. At the dyadic level, tie duration and multiplexityare being suggested. At the network level the portfolio structure of ties, termed network coupling by Uzzi and Gillespie, can serve as a basis for measurement. This item captures how dispersed or consolidated business volume between alters is. Network size and industry effects need to be controlled for, the problem of relevant net work boundaries remains. It is proposed that an intermediate level of embeddedness is required to negotiate and implement contracts, there may be a saturation point at which contracts lose importance due to the increasing closeness between parties:

Proposition3: The relationship between embeddedness and the extent of supply chain contract usage follows an inverted U-shape.

In addition to the three stages above, there are considerations to extend the investigation of SCCs. To identify the reasons for non-use of supply chain contracts could add value to the analysis and help to specify future research designs. Companies that use supply chain contracts with selected vendors but not with others may provide insight into the conditions, the process, benefits and consequences of contract useand non-use. Global corporations need to consider risk management, warranty, as well as the consolidation and integration of sometimes conflicting business and supply chain contracts throughout a supply chain. Other potentially relevant aspects are existing knowledge of contract usage and process sophistication, negotiation and control costs, organizational structure to support supply chain coordination and the firm's position in the supply chain.

\section{Data and Methods}

The scarcity of social network analysis research in the SCM literature is partly related to data collection. Especially in the case of whole network designs and contract research, confidentiality concerns will be an issue, and the availability of secondary data will be marginal at best. A starting point could be to gather domestic case data of firms in two or three different industries. The snowballing approach to data collection can be employed to generate cases(Stephen P. Borgatti \& Li, 2009). Trust is an important antecedent when collecting data, possibly disqualifying a regular online or paper survey as instruments at this exploratory stage. The face-to-face, casebased data collection approach is recommended, to establish a basic understanding of important factors and to validate suggested concepts in this complex and underexplored research area (Eisenhardt, 1989). Even though the three proposed models for inquiry call for a large set of questions, the chosen concepts rely in part on the same measurement items. Ego networks do not require an exhaustive list of firms, the names of participants or companies do not have to be reported, and the response rate can be lower than in full network data collection (Balkundi, Prasad, 2013; Kim, Choi, Yan, \& Dooley, 2011). In complex organizations, it may be necessary to ask for the same information from several organizational members to construct a full ego network and for triangulation purposes. The focus on ego networks will allow analyzing richer and deeper data about the multiplexity of ego/alter relationships. To enhance results, an 'extended' ego network with two tiers of suppliers or also customers could be planned. Network boundaries can be defined based on relative frequency (intensity) of interactions, based on the membership perceived by actors (realist approach) or the theoretical concerns of the researcher (nominalist approach) (Wasserman \& Faust, 1994). Data collection in ego networks includes five steps: collecting attributes about ego, name generator (obtain a list of alters), name interpreter (relationship between ego and alters), alter attributes and finally, info about the alter-alter relationships. Data can be collected through interviews and follow-up surveys. 
Graphs and ego network measures can be computed for each case to analyze the structural effects, such as the impact of connections between suppliers or the portfolio structure of suppliers. Software for this type of analysis is available and has been tested(S. P. Borgatti, 2006; Everett \& Borgatti, 2005). A control group of firms that does not use SCCs will validate and enrich results.

\section{Conclusion}

The three proposed research design stages have a strong potential to contribute to a topic of high practical relevance for firms, entire supply chains, and economic regions. Theory was enhanced in several ways: a) An attempt was made to clearly distinguish between transactional contracts and supply chain contracts which intend to improve overall supply chain effectiveness and profits. b) The importance to explore multiplexity in inter-firm relationships was elevated, and relevant supply chain relationship characteristics were outlined.c)Measurement items and constructs for a structural model were suggested. d) The application of the embeddedness concept in combination with and based on network theory is novel to SCC research. e) The suggested case-based methodology can help to identify important antecedents and conditions of supply chain contract use and nonuse(Barratt, Choi, \& Li, 2011).

Not every inter-firm link demands closely managed relationships or contracts, but insights from existingdyads with supply chain contracts can help to provide an understanding of the antecedents, mechanisms, and outcomes. Even minor improvements in supply chain contract usage through better integration and policy have the potential for large economic gains.

\section{Bibliography}

Adler, P. S., \& Kwon, S.-W. (2002). Social capital: Prospects for a new concept. Academy of Management Review, 27(1), 17-40.

Arregle, J.-L., Hitt, M. A., Sirmon, D. G., \& Very, P. (2007). The Development of Organizational Social Capital: Attributes of Family Firms. Journal of Management Studies, 44(1), 73-95.

Balkundi, P., \& Kilduff, M. (2006). The ties that lead: A social network approach to leadership. The Leadership Quarterly, 17(4), 419-439.

Balkundi, Prasad. (2013). MGB 702 - Social Networks and Organizations. Doctoral Seminar (notes), University at Buffalo.

Barratt, M., Choi, T. Y., \& Li, M. (2011). Qualitative case studies in operations management: trends, research outcomes, and future research implications. Journal of Operations Management, 29(4), 329-342.

Baum, J. A., \& Oliver, C. (1992). Institutional embeddedness and the dynamics of organizational populations. American Sociological Review, 540-559.

Bergman, J. (2013, June). Case study shows the Relational Contracting Model may be changing the contracting process. IACCM - Contracting Excellence. Retrieved from

http://www.iaccm.com/news/contractingexcellence/?storyid=1466

Borgatti, S. P. (2006). E-NET software for the analysis of ego-network data. Needham, MA: Analytic Technologies.

Borgatti, Stephen P., \& Li, X. (2009). On Social Network Analysis in a Supply Chain Context. Journal of Supply Chain Management, 45(2), 5-22.

Borgatti, Stephen P., Mehra, A., Brass, D. J., \& Labianca, G. (2009). Network analysis in the social sciences. Science, 323(5916), 892-895.

Burt, R. S. (1992). The social structure of competition. Networks and Organizations: Structure, Form, and Action, 57-91.

Cachon, G. P. (2003). Supply chain coordination with contracts. Handbooks in Operations Research and Management Science, 11, 229-340.

Carey, S., Lawson, B., \& Krause, D. R. (2011). Social capital configuration, legal bonds and performance in buyer-supplier relationships. Journal of Operations Management, 29(4), 277-288.

Dyer, J. H., \& Singh, H. (1998). The relational view: Cooperative strategy and sources of interorganizational competitive advantage. Academy of Management Review, 23(4), 660-679.

Eisenhardt, K. M. (1989). Building theories from case study research. Academy of Management Review, 14(4), 532-550. 
Everett, M., \& Borgatti, S. P. (2005). Ego network betweenness. Social Networks, 27(1), 31-38.

Flynn, B. B., Huo, B., \& Zhao, X. (2010). The impact of supply chain integration on performance: a contingency and configuration approach. Journal of Operations Management, 28(1), 58-71.

Forrester, J. W. (1958). Industrial dynamics: a major breakthrough for decision makers. Harvard Business Review, 36(4), 37-66.

Fugate, B., Sahin, F., \& Mentzer, J. T. (2006). Supply chain management coordination mechanisms. Journal of Business Logistics, 27(2), 129-161.

Gabbay, S. M., \& Leenders, R. T. A. (2001). Social capital of organizations: From social structure to the management of corporate social capital (Vol. 18). Emerald Group Publishing Limited.

Geyskens, I., Steenkamp, J.-B. E., \& Kumar, N. (2006). Make, buy, or ally: a transaction cost theory metaanalysis. Academy of Management Journal, 49(3), 519-543.

Ghoshal, S., \& Moran, P. (1996). Bad for practice: A critique of the transaction cost theory. Academy of Management Review, 21(1), 13-47.

Goffin, K., Lemke, F., \& Szwejczewski, M. (2006). An exploratory study of 'close'supplier-manufacturer relationships. Journal of Operations Management, 24(2), 189-209.

Granovetter, M. (1985). Economic action and social structure: the problem of embeddedness. American Journal of Sociology, 481-510.

Grover, V., \& Malhotra, M. K. (2003). Transaction cost framework in operations and supply chain management research: theory and measurement. Journal of Operations Management, 21(4), 457-473.

Gulati, R. (1995). Does familiarity breed trust? The implications of repeated ties for contractual choice in alliances. Academy of Management Journal, 38(1), 85-112.

Gulati, R., \& Singh, H. (1998). The architecture of cooperation: Managing coordination costs and appropriation concerns in strategic alliances. Administrative Science Quarterly, 781-814.

Ha, A. Y., \& Tong, S. (2008). Contracting and information sharing under supply chain competition. Management Science, 54(4), 701-715.

Hanneman, R. A., \& Riddle, M. (2005). Introduction to social network methods. Retrieved from http://faculty.ucr.edu/ hanneman/nettext/

Hart, O., \& Moore, J. (1988). Incomplete contracts and renegotiation. Econometrica: Journal of the Econometric Society, 755-785.

Hess, M. (2004). 'Spatial relationships?' Towards a reconceptualization of embeddedness.' Progress in Human Geography, 28(2), 165-186.

Höhn, M. I. (2010). Relational supply contracts: optimal concessions in return policies for continuous quality improvements (Vol. 629). Springer.

Kane, G. C., Alavi, M., Labianca, G. (Joe), \& Borgatti, S. (2012). What's Different About Social Media Networks? A Framework and Research Agenda (SSRN Scholarly Paper No. ID 2239249). Rochester, NY: Social Science Research Network. Retrieved from http://papers.ssrn.com/abstract=2239249

Kay, J. (2010, March 17). Think before you tear up an unwritten contract. Financial Times. Retrieved from http://www.ft.com/intl/cms/s/0/458c9946-3164-11df-9741-00144feabdc0.html\#axzz2rZ485acu

Kim, Y., Choi, T. Y., Yan, T., \& Dooley, K. (2011). Structural investigation of supply networks: A social network analysis approach. Journal of Operations Management, 29(3), 194-211.

Kroes, J. R., \& Ghosh, S. (2010). Outsourcing congruence with competitive priorities: impact on supply chain and firm performance. Journal of Operations Management, 28(2), 124-143.

Lambert, D. M., Emmelhainz, M. A., \& Gardner, J. T. (1996). Developing and implementing supply chain partnerships. International Journal of Logistics Management, The, 7(2), 1-18.

Larson, A. (1992). Network dyads in entrepreneurial settings: A study of the governance of exchange relationships. Administrative Science Quarterly, 76-104.

Lawrence, P. R., Lorsch, J. W., \& Garrison, J. S. (1967). Organization and environment: Managing differentiation and integration. Division of Research, Graduate School of Business Administration, Harvard University Boston, MA.

Lazzarini, S. G., Chaddad, F. R., \& Cook, M. L. (2001). Integrating supply chain and network analyses: the study of netchains. Journal on Chain and Network Science, 1(1), 7-22.

Li, L., \& Zhang, H. (2008). Confidentiality and information sharing in supply chain coordination. Management Science, 54(8), 1467-1481. 
Lincoln, J. R., \& Miller, J. (1979). Work and friendship ties in organizations: A comparative analysis of relation networks. Administrative Science Quarterly, 181-199.

Long Lingo, E., \& O’Mahony, S. (2010). Nexus work: Brokerage on creative projects. Administrative Science Quarterly, 55(1), 47-81.

Macneil, I. R. (1973). Many Futures of Contracts, The. S. Cal. L. Rev., 47, 691.

Nahapiet, J., \& Ghoshal, S. (1998). Social capital, intellectual capital, and the organizational advantage. Academy of Management Review, 23(2), 242-266.

Narayanan, V. G., \& Raman, A. (2004). Aligning incentives in supply chains. Harvard Business Review, 82(11), 94.

Oh, H., Labianca, G., \& Chung, M.-H. (2006). A multilevel model of group social capital. Academy of Management Review, 31(3), 569-582.

Petkova, B. (2013). Power and Supply Chain Integration.

Pfeffer, J., \& Salancik, G. (1978). The external control of organizations: A resource dependence perspective. Harper \& Row, Publishers, Inc.

Poppo, L., \& Zenger, T. (2002). Do formal contracts and relational governance function as substitutes or complements? Strategic Management Journal, 23(8), 707-725.

Powell, W. (1990). Neither market nor hierarchy: Network forms of organization. Research in Organizational Behavior, 12, 295-336.

Powell, W. W. (1991). The new institutionalism in organizational analysis. University of Chicago Press.

Rooks, G., Raub, W., Selten, R., \& Tazelaar, F. (2000). How inter-firm co-operation depends on social embeddedness: A vignette study. Acta Sociologica, 43(2), 123-137.

Shipilov, A. V., \& Li, S. X. (2008). Can you have your cake and eat it too? Structural holes' influence on status accumulation and market performance in collaborative networks. Administrative Science Quarterly, 53(1), 73-108.

Simchi-Levi, D., Kaminsky, P., \& Simchi-Levi, E. (2008). Designing and managing the supply chain: concepts, strategies, and case studies (3rd ed.). Boston: McGraw-Hill/Irwin.

Spengler, J. J. (1950). Vertical integration and antitrust policy. The Journal of Political Economy, 58(4), 347-352.

Tsai, W., \& Ghoshal, S. (1998). Social Capital and Value Creation: The Role of Intrafirm Networks. The Academy of Management Journal, 41(4), 464-476.

Tsay, A. A., Nahmias, S., \& Agrawal, N. (1999). Modeling supply chain contracts: A review. In Quantitative models for supply chain management (pp. 299-336). Springer. Retrieved from http://link.springer.com/chapter/10.1007/978-1-4615-4949-9_10

Uzzi, B. (1997). Social structure and competition in interfirm networks: The paradox of embeddedness. Administrative Science Quarterly, 35-67.

Uzzi, B., \& Gillespie, J. J. (1999). Corporate social capital and the cost of financial capital: An embeddedness approach. In Corporate social capital and liability (pp. 446-459). Springer.

Ward, P. T., McCreery, J. K., Ritzman, L. P., \& Sharma, D. (1998). Competitive priorities in operations management. Decision Sciences, 29(4), 1035-1046.

Wasserman, S., \& Faust, K. (1994). Social network analysis: Methods and applications (Vol. 8). Cambridge university press.

Williamson, O. E. (1979). Transaction-Cost Economics: The Governance of Contractual Relations. Journal of Law and Economics, 22(2), 233-261.

Zaheer, A., Gulati, R., \& Nohria, N. (2000). Strategic networks. Strategic Management Journal, 21(3), 203.

Zaheer, A., McEvily, B., \& Perrone, V. (1998). Does trust matter? Exploring the effects of interorganizational and interpersonal trust on performance. Organization Science, 9(2), 141-159.

Zukin, S., \& DiMaggio, P. (1990). Structures of capital: The social organization of the economy. CUP Archive. 